\title{
Effective Drug Delivery System for Duchenne Muscular Dystrophy Using Hybrid Liposomes Including Gentamicin along with Reduced Toxicity
}

\author{
Mamiko Yukihara, ${ }^{a}$ Kaori Ito, ${ }^{b}$ Osamu Tanoue, ${ }^{a}$ Koichi Goto, ${ }^{a}$ Taku Matsushita, ${ }^{a}$ \\ Yoko Matsumoto, ${ }^{a}$ Masako Masuda, ${ }^{c}$ Shigemi Kimura, ${ }^{*, b}$ and Ryuichi UeokA ${ }^{*, a}$ \\ ${ }^{a}$ Division of Applied Life Science, Graduate School of Engineering, Sojo University; 4-22-1 Ikeda, Kumamoto 860-0082, \\ Japan: ${ }^{b}$ Department of Child Development, Kumamoto University Graduate School; and ${ }^{c}$ Department of Otolaryngology, \\ Kumamoto University Graduate School; 1-1-1 Honjo, Kumamoto 860-0811, Japan. \\ Received December 14, 2010; accepted January 28, 2011; published online February 7, 2011
}

It is known that gentamicin (GM) could be a possible treatment for Duchenne Muscular Dystrophy (DMD). However, GM therapy has been hindered by several problems such as severe side effects of GM. In order to resolve these problems, we developed the drug delivery system (DDS) of GM using hybrid liposomes (HL) composed of $L-\alpha$-dimyristoylphosphatidylcholine (DMPC) and polyoxyethylene (23) lauryl ether $\left(\mathrm{C}_{12}(\mathrm{EO})_{23}\right)$. The hydrodynamic diameters of HL including GM (GM-HL) were $60-90 \mathrm{~nm}$ with a narrow range of the size distribution and the sizes were kept almost constant for over 4 weeks, suggesting that GM-HL could avoid the reticuloendothelial system in vivo. Furthermore, GM-HL accumulated more to the skeletal muscle cells of $\mathrm{X}$ chromosomelinked muscular distrophy $(\mathrm{mdx})$ mice as compared to those of normal mice. Significantly, we succeeded in increasing dystrophin positive fibers in skeletal muscle cells of mdx mice using GM-HL along with the reduction of ototoxicity. It is suggested that GM should be carried more efficiently into the muscular cells of mdx mice by HL. These results indicate that HL could be an effective carrier in the DDS of GM therapy for DMD.

Key words Duchenne muscular dystrophy; hybrid liposome; gentamicin; drug delivery system; X chromosome-linked muscular distrophy mouse

Duchenne/Becker muscular dystrophy (DMD/BMD) is caused by a defective expression of the dystrophin gene resulting in the absence of the dystrophin protein in muscle fibers. ${ }^{1,2)}$ Approximately $60 \%$ of DMD/BMD patients have deletions in the dystrophin gene itself, ${ }^{3-5)}$ while the remaining $40 \%$ have small deletions or point mutations in the region that encodes the gene. Furthermore, nonsense mutations located within the gene account for approximately $5-13 \%$ of the muscular dystrophies. ${ }^{6,7)}$

Aminoglycoside antibiotics such as gentamicin (GM) had the ability to allow the ribosome to read through a premature-termination codon of the dystrophin gene, which prevented normal translation of dystrophin protein. ${ }^{8,9)}$ BartonDavis et al. demonstrated the possibility of treating X chromosome-linked muscular distrophy ( $\mathrm{mdx}$ ) mouse, which was an animal model for DMD that possessed a nonsense mutation in the dystrophin gene, with GM in vivo. ${ }^{10)}$ They used GM to suppress the nonsense mutations and could restore dystrophin expression successfully in mdx mouse. However, the GM therapy has been hindered by several problems such as severe side effects of GM, especially nephrotoxicity and ototoxicity, the poor delivery profile to muscle tissue, and short half-life in blood. Recently, the phase $2 \mathrm{~b}$ clinical trial of PTC 124 (3-[5-(2-fluorophenyl)-[1,2,4]oxadiazol-3-yl]benzoic acid), ${ }^{11)}$ which is a new drug to induce reading through a premature-termination codon without clear side-effects, showed that the primary endpoint of the change in 6 min walk distance tests did not reach any statistical significance within the 48 weeks duration of the study according to Genzyme corporation announcement. ${ }^{12}$

Therefore, to overcome these inadequacies of GM therapy for DMD, we encapsulated GM in hybrid liposomes (HL) for the delivery system. HL can be prepared by just the sonication of vesicular and micellar molecules in a buffer solution. ${ }^{13,14)} \mathrm{HL}$ are free from any contamination with organic solvents and remain stable for longer periods. The physical properties of these liposomes such as size, membrane fluidity, phase transition temperature, and hydrophobicity can be controlled by changing the constituents and compositional ratios. In the course of our study for HL, the following interesting results have been obtained. (a) Stereochemical control of the enantioselective hydrolysis of amino acid esters could be established by temperature regulation and changing the composition of the HL. ${ }^{12,13)}$ (b) Inhibitory effects of HL including antitumor drugs, ${ }^{15)}$ sugar surfactants, ${ }^{16)}$ or polyunsaturated fatty acids ${ }^{17)}$ have been observed on the growth of tumor cells in vitro and in vivo. (c) High inhibitory effects of $\mathrm{HL}$ on the growth of tumor cells along with the induction of apoptosis in vitro $^{18)}$ and in vivo ${ }^{19}$ have been obtained without using drugs. ${ }^{20)}$ Successful clinical chemotherapy with drug-free HL to patients with lymphoma has been reported after passing the committee of bioethics. ${ }^{21)}$ (d) A good correlation between membrane fluidity of HL and antitumor effects on the growth of tumor cells has been observed. ${ }^{22}$ These studies indicate that HL had no cytotoxicity and could be effective carriers for improving solubilization and stabilization of hydrophilic ${ }^{23)}$ and hydrophobic agents in the drug delivery system (DDS).

In this study, we reported the therapeutic effects of HL including GM (GM-HL) on the mdx mice in vivo. The reduction of side effects of GM-HL is also discussed on the basis of the results from auditory brainstem response (ABR) tests and biodistribution analysis of HL.

\section{MATERIALS AND METHODS}

Preparation of HL, GM-HL and NBD-HL HL were prepared by sonication of a mixture containing $95 \mathrm{~mol} \% \mathrm{~L}-\alpha$ dimyristoylphosphatidylcholine (DMPC) (NOF, Tokyo, Japan) and $5 \mathrm{~mol} \%$ polyoxyethylene(23) lauryl ether $\left(\mathrm{C}_{12}(\mathrm{EO})_{23}\right)$ (Sigma-Aldrich, St. Louis, MO, U.S.A.) using a bath type soni- 
cator (VS-N300, VELVO-CLEAR, Tokyo, Japan) in phosphate buffered saline $(\operatorname{PBS}(-))$ at $45^{\circ} \mathrm{C}$ with $300 \mathrm{~W}$, and filtered with a $0.20 \mu \mathrm{m}$ cellulose acetate filter (ADVANTEC, Tokyo, Japan). HL including GM (GM-HL) or 1-palmitoyl-2-[12-[(7-nitro-21,3-benzoxadiazol-4-yl)amino]dodecanoyl]-sn-glycero-3-phosphocholine (NBDPC) (NBD-HL) were prepared with GM (Schering-Plough, Kenilworth, NJ, U.S.A.) or NBDPC (Avanti Polar Lipids, Alabaster, AL, U.S.A.) by the same method of HL, respectively.

Dynamic Light Scattering Measurement Apparent mean hydrodynamic diameters $\left(d_{\text {hy }}\right)$ of HL, GM-HL and NBD-HL were measured using a light scattering spectrometer (ELS-8000, Otsuka Electronics, Osaka, Japan) with a $\mathrm{He}-\mathrm{Ne}$ laser light source $(633 \mathrm{~nm})$. The diameter was calculated by Stokes-Einstein equation (Eq. (1)),

$$
d_{\text {hy }}=(\kappa T) /(3 \pi \eta D)
$$

where $\kappa$ is Boltzmann constant, $T$ is the absolute temperature, $\eta$ is the viscosity of the solvent and $D$ is the diffusion coefficient.

Electron Microscopy Electron micrographs of GM-HL were obtained by means of a negative-staining method. Sample solutions of GM-HL were mixed with a $4 \%$ aqueous solution of ammonium molybdate. The sample was then applied to a carbon grid and dried overnight in a vacuum desiccator at room temperature. The electron micrographs were taken on an electron microscope (JEM-100SX, JEOL, Tokyo, Japan).

Therapeutic Experiment of GM-HL in Vivo All animal experiments were approved by the committee of the Center for Animal Resources and Development, Kumamoto University, Japan. Eight-week-old mdx mice, which have a stop codon TAA in exon 23 of the dystrophin gene, were intraperitonealy injected with either GM-HL, GM alone or HL. The given dosages of GM were $1 \times(34 \mathrm{mg} / \mathrm{kg} / \mathrm{d}), 5 \times$ $(170 \mathrm{mg} / \mathrm{kg} / \mathrm{d})$, and $10 \times(340 \mathrm{mg} / \mathrm{kg} / \mathrm{d})$. The number of mice for GM-HL $1 \times$, GM-HL $5 \times$, GM-HL $10 \times$, GM 1×, GM $10 \times$, HL $1 \times$, HL $5 \times$, and control (non-treated) were $3,2,1$, $3,7,3,2$, and 5, respectively. After 2 weeks of the injection (3 times/d), the skeletal muscles were isolated, and the blood samples were collected from the treated mice. The efficiency of dystrophin positive fibers was calculated by the average number of dystrophin positive fibers in 3 randomly chosen photographs of dystrophin immunostaining skeletal muscle tissues per mouse. The creatine kinase $(\mathrm{CK})$ and creatinine levels of each mouse were measured by a laboratory examination agency (SRL, Tokyo, Japan).

Immunochemical Staining of Dystrophin and Histological Analysis Skeletal muscles from gastrocnemius of treated mdx mice were frozen in isopentane pre-cooled in liquid nitrogen and $10-\mu \mathrm{m}$-thick sections were cut with a cryostat. The expression of dystrophin was analyzed with mouse monoclonal anti-dystrophin antibody (DYS2; $1: 25$, Novacastra Laboratories, Newcastle, U.K.) and biotinylated anti-mouse immunoglobulin $\mathrm{G}$ (IgG) reagent (VECTOR M.O.M. Immunodetection Kit, Vector Laboratories, Burlingame, CA, U.S.A.) as the secondary antibody. The immunoreactivity was visualized using 3,3'-diaminobenzidine as the chromogen substrate. The average number of dystrophin positive fibers was counted on 3 photographs that were randomly taken per mouse.
Confocal Laser Microscopy The accumulation of fluorescence-labeled HL (NBD-HL) ${ }^{24)}$ to the skeletal muscle was observed using confocal laser microscopy (CLM). NBD-HL were intraperitonealy injected into normal (B10, 8-week-old) and mdx mice. After the injection, the skeletal muscles (gastrocnemius) were isolated from the mice each time $(1,2,6 \mathrm{~h})$. The dissected muscles were embedded in an OCT compound and rapidly frozen. The cryosections of each muscle were made and stained with TO-PRO-3 dye (Invitrogen, Carlsbad, CA, U.S.A.) solution including an antifade reagent $(0.5 \%$ 1,4-di-azobicyclo-(2,2,2)-octane) for detecting the cell nucleus. The sections were observed using CLM (TCS-SP, Leica Microsystems, Wetzlar, Germany) with $488 \mathrm{~nm} \mathrm{Ar}$ laser line for NBDPC detection (emission; 500-600 nm) and $633 \mathrm{~nm}$ He-Ne laser line for TO-PRO-3 detection (emission; $640-703 \mathrm{~nm}$ ). The biodistribution of NBD-HL to the organs of mdx mice was also observed using CLM. NBD-HL were intravenously injected into the mdx mice. After $1 \mathrm{~h}$ of the injection, the organs (brain, lung, liver, heart, kidney, spleen and skeletal muscle) were isolated from the mice. The dissected organs were embedded in an OCT compound and their cryosections were stained with TO-PRO-3 and observed using CLM as described above.

Auditory Brainstem Response (ABR) Female (8-weekold, $n=1)$ and male ( 8 -week-old, $n=7) \mathrm{mdx}$ mice were treated with GM-HL $10 \times$ and GM $10 \times$ for $14 \mathrm{~d}$, respectively. After 2 weeks of the intraperitoneal (i.p.) injection (3 times/d), the hearing ability was determined by the auditory brainstem response (ABR). $\left.{ }^{25}\right) \mathrm{ABR}$ was obtained from mice anesthetized with a mixture of nitrous oxide/oxygen $(1: 1)$ gas and $3 \%$ halothane. Responses were differentially recorded between subcutaneous stainless steel electrodes at the vertex (active) and mastoid (reference), and the lower back served as ground. Testing was performed in a soundattenuated box. The ABR, response to the sound of clicks, were recorded using a signal processor (Neuropack $\mu$, Nihon Kohden, Tokyo, Japan).

Statistical Analysis Statistical analysis was performed by Student's $t$-test. A confidence level $p<0.05$ was considered significant.

\section{RESULTS}

Morphology of HL, GM-HL and NBD-HL Morphologies of HL, GM-HL and NBD-HL were examined on the basis of dynamic light scattering measurements and electron microscopy. The hydrodynamic diameters $\left(d_{\text {hy }}\right)$ of HL, GMHL and NBD-HL were almost the same sizes of $60-90 \mathrm{~nm}$ with a narrow range of size distribution (Fig. 1A). The diameters remained stable for more than 4 weeks. An electron micrograph of GM-HL showed the presence of spherical vesicles with a diameter of $60-90 \mathrm{~nm}$ as shown in Fig. 1B.

Accumulation of HL to Muscle Cells in Vivo The accumulation of NBD-HL to the skeletal muscle cells of normal (B10) and mdx mice in vivo was observed using CLM. The results are shown in Fig. 2. The green fluorescence of NBD-HL was detected in the cytoplasm and cytoplasmic membranes of myofibers of normal and mdx mice. Interestingly, the NBD-HL accumulated more in the cytoplasmic membranes of mdx mice (Fig. 2B) after $1 \mathrm{~h}$ of the i.p. injection as compared with those of normal mice (Fig. 2A). Then, 


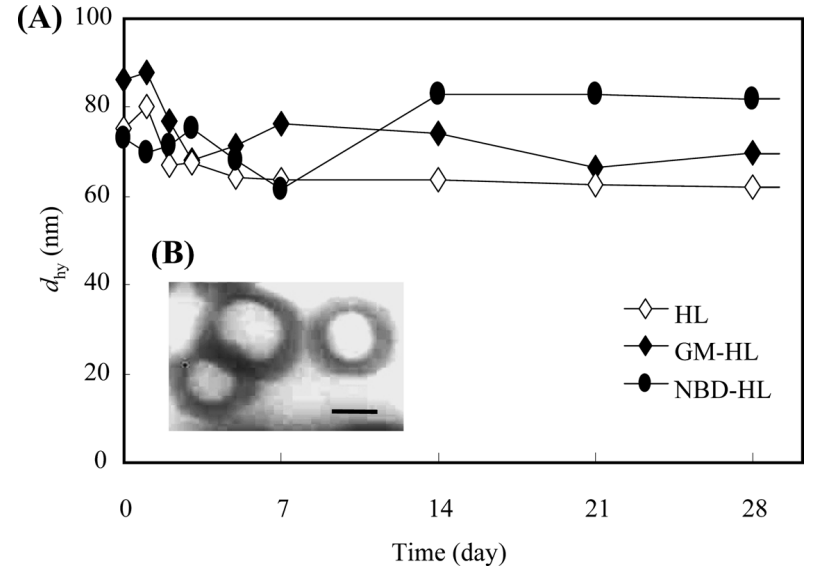

Fig. 1. Morphology of HL, GM-HL and NBD-HL

(A) Time courses of hydrodynamic diameters $\left(d_{\mathrm{hy}}\right)$ change for HL, GM-HL and NBD-HL prepared by sonication method. The $d_{\text {by }}$ of HL, GM-HL and NBD-HL were measured using a light scattering spectrometer at $25^{\circ} \mathrm{C}$. $\mathrm{HL}$ and GM-HL: [DMPC] $=$ $30 \mathrm{~mm},\left[\mathrm{C}_{12}(\mathrm{EO})_{23}\right]=1.58 \mathrm{~mm},[\mathrm{GM}]=10 \mathrm{mg}($ potency $) / \mathrm{ml}$. NBD-HL: [DMPC] $=10 \mathrm{mM}$ $\left[\mathrm{C}_{12}(\mathrm{EO})_{23}\right]=0.549 \mathrm{~mm},[\mathrm{NBDPC}]=0.439 \mathrm{~mm}$. (B, inset) An electron micrograph of GM-HL by a negative staining method. $[\mathrm{DMPC}]=10 \mathrm{mM},\left[\mathrm{C}_{12}(\mathrm{EO})_{23}\right]=0.526 \mathrm{~mm}$, $[\mathrm{GM}]=3.33 \mathrm{mg}$ (potency) $/ \mathrm{ml}$. Scale bar: $50 \mathrm{~nm}$.

(A) Normal mouse (B10)
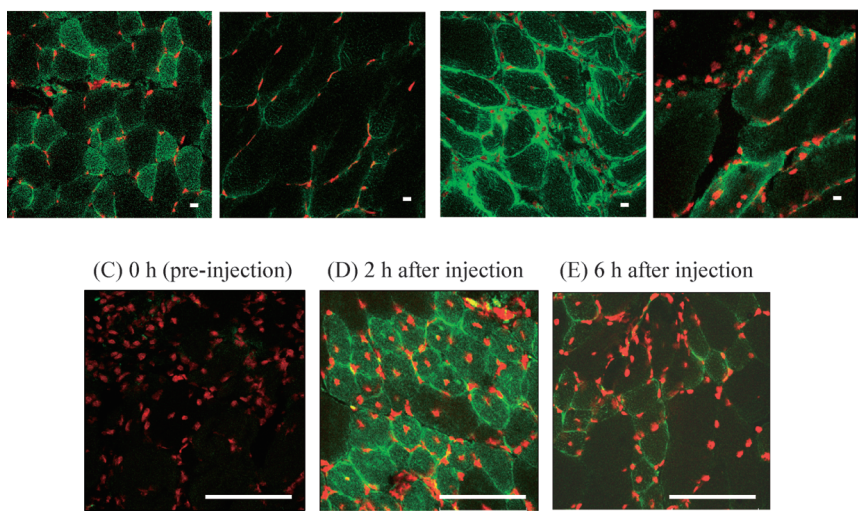

Fig. 2. Fluorescence Micrographs of Skeletal Muscle Cells for Normal and Mdx Mice after the i.p. Injection of NBD-HL

After the i.p. injection of NBD-HL into normal (B10) and mdx mice, the skeletal muscles were isolated from the mice, the cryosections of each muscle were stained with TO-PRO-3, and the stained sections were observed using CLM. Green: NBD-HL, Red: TO-PRO-3. (A) Normal and (B) mdx mice after $1 \mathrm{~h}$ of the injection of NBD-HL. Mdx mice after (C) $0 \mathrm{~h}$ (pre-injection), (D) $2 \mathrm{~h}$ and (E) $6 \mathrm{~h}$ of the injection of NBD-HL. Dose: $[\mathrm{DMPC}]=67.98 \mathrm{mg} / \mathrm{kg},\left[\mathrm{C}_{12}(\mathrm{EO})_{23}\right]=6.59 \mathrm{mg} / \mathrm{kg},[\mathrm{NBDPC}]=3.76 \mathrm{mg} / \mathrm{kg}$. Scale bar: (A) (B) $10 \mu \mathrm{m}$, (C) (D) (E) $100 \mu \mathrm{m}$.

we investigated the retention time of NBD-HL in the myofibers of mdx mice. The higher fluorescence intensity of NBD-HL was observed in the myofibers of mdx mice after $2 \mathrm{~h}$ of the i.p. injection (Fig. 2D) compared with that of preinjection (Fig. 2C). Furthermore, the fluorescence intensity of NBD-HL was consecutively observed after $6 \mathrm{~h}$ of the injection (Fig. 2E).

Therapeutic Effects of GM-HL on Mdx Mice in Vivo The therapeutic effects of GM-HL on mdx mice were investigated in vivo. Generally, the $\mathrm{CK}$ level indicates the degree of muscle necrosis and the average CK level of mdx mice (control) in this experiment was $4239 \pm 501.1$ (IU/1) as shown in Fig. 3. On the other hand, after 2 weeks of the i.p. injection, the average CK levels of GM-HL $1 \times, 5 \times$, and $10 \times$ injected $\mathrm{mdx}$ mice decreased to $685 \pm 140$ (IU/1), $759 \pm 122$ (IU/1) and 610 (IU/1), respectively. The average CK levels of GM $1 \times$

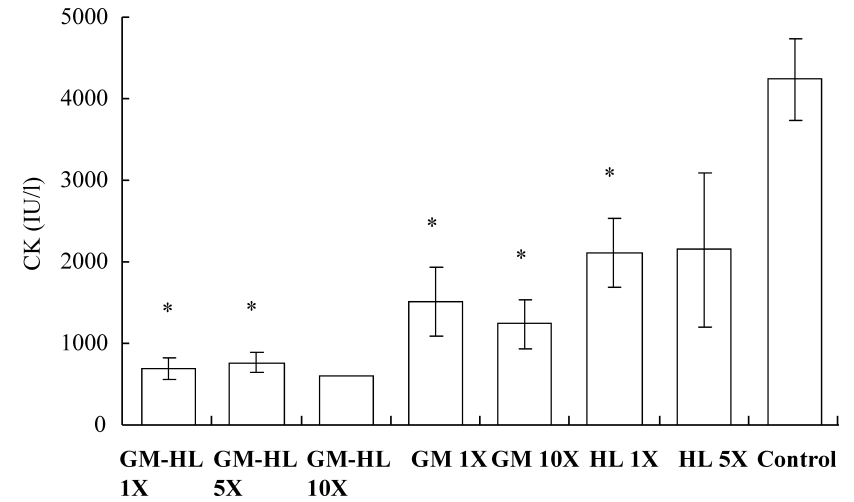

Fig. 3. CK Level in Blood of Mdx Mice after the Treatment with GM-HL, GM and $\mathrm{HL}$

After 2 weeks of injection ( 3 times/d), the blood was collected from the treated $\mathrm{mdx}$ mice and the creatine kinase (CK) level of each mouse was measured. Data represent the mean \pm S.E. $(n=1-6)$. Control means a CK level of the untreated mdx mice. Dose: GM-HL 1 $1 \times: \quad[\mathrm{DMPC}]=694.0 \mathrm{mg} / \mathrm{kg} / \mathrm{d}, \quad\left[\mathrm{C}_{12}(\mathrm{EO})_{23}\right]=64.39 \mathrm{mg} / \mathrm{kg} / \mathrm{d}, \quad[\mathrm{GM}]=34 \mathrm{mg} /$ $\mathrm{kg} / \mathrm{d}, \mathrm{GM}-\mathrm{HL} 5 \times:[\mathrm{DMPC}]=3470 \mathrm{mg} / \mathrm{kg} / \mathrm{d},\left[\mathrm{C}_{12}(\mathrm{EO})_{23}\right]=322.0 \mathrm{mg} / \mathrm{kg} / \mathrm{d},[\mathrm{GM}]=170$ $\mathrm{mg} / \mathrm{kg} / \mathrm{d}, \mathrm{GM}-\mathrm{HL} 10 \times:[\mathrm{DMPC}]=6940 \mathrm{mg} / \mathrm{kg} / \mathrm{d},\left[\mathrm{C}_{12}(\mathrm{EO})_{23}\right]=643.9 \mathrm{mg} / \mathrm{kg} / \mathrm{d},[\mathrm{GM}]=$ $340 \mathrm{mg} / \mathrm{kg} / \mathrm{d}, \mathrm{GM} 1 \times:[\mathrm{GM}]=34 \mathrm{mg} / \mathrm{kg} / \mathrm{d}, \mathrm{GM} 10 \times:[\mathrm{GM}]=340 \mathrm{mg} / \mathrm{kg} / \mathrm{d}, \mathrm{HL} 1 \times$ : $\left[\right.$ DMPC] $=694.0 \mathrm{mg} / \mathrm{kg} / \mathrm{d},\left[\mathrm{C}_{12}(\mathrm{EO})_{23}\right]=64.39 \mathrm{mg} / \mathrm{kg} / \mathrm{d}, \mathrm{HL} 5 \times:[\mathrm{DMPC}]=3470 \mathrm{mg} / \mathrm{kg}$ d, $\left[\mathrm{C}_{12}(\mathrm{EO})_{23}\right]=322.0 \mathrm{mg} / \mathrm{kg} / \mathrm{d}$. * Significant difference $(p<0.05)$ compared with control.

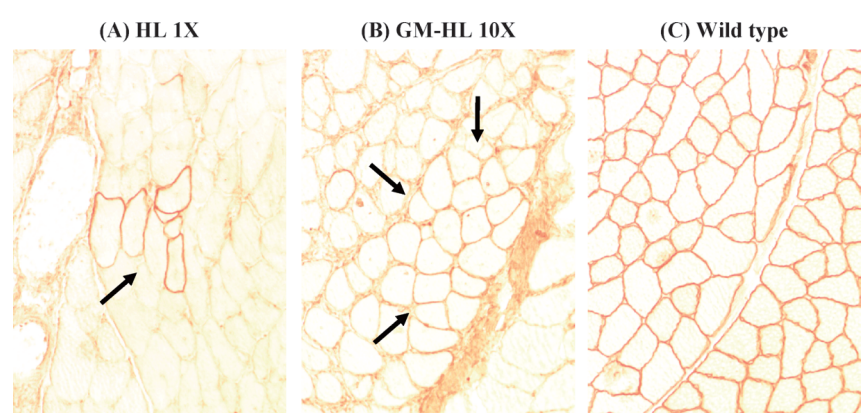

(D)

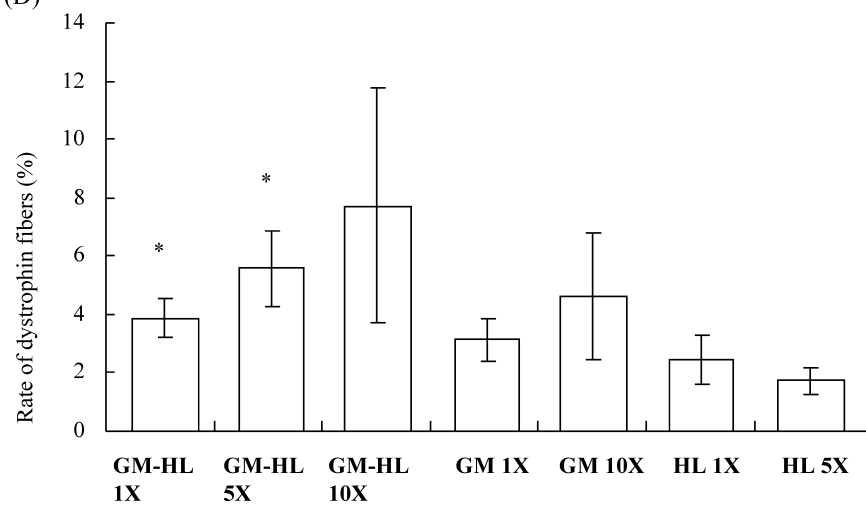

Fig. 4. Expression of Dystrophin in Skeletal Muscle Tissues of Mdx Mice after the Treatment with GM-HL, GM and HL

After 2 weeks injection ( 3 times/d), skeletal muscles were isolated from the treated mice and the expression of dystrophin was analyzed with mouse monoclonal anti-dystrophin antibody and biotinylated anti-mouse IgG reagent. The immunoreactivity was visualized using 3,3'-diaminobenzidine and the average number of dystrophin positive fibers was counted on 3 photographs that were randomly taken per mouse. Dystrophin immunostaining of skeletal muscle tissues was isolated from (A) HL $1 \times$ treated $\mathrm{mdx}$ mice, (B) GM-HL $10 \times$ treated $\mathrm{mdx}$ mice and $(\mathrm{C})$ untreated normal mice (Wild type). (D) Rate of dystrophin positive fiber in skeletal muscle tissues of GM-HL, GM and HL treated $\mathrm{mdx}$ mice. $*$ Significant difference $(p<0.05)$ compared with HL $5 \times$. Dose: GM$\mathrm{HL} 1 \times:[\mathrm{DMPC}]=694.0 \mathrm{mg} / \mathrm{kg} / \mathrm{d}, \quad\left[\mathrm{C}_{12}(\mathrm{EO})_{23}\right]=64.39 \mathrm{mg} / \mathrm{kg} / \mathrm{d}, \quad[\mathrm{GM}]=34 \mathrm{mg} / \mathrm{kg} / \mathrm{d}$ GM-HL $5 \times:[\mathrm{DMPC}]=3470 \mathrm{mg} / \mathrm{kg} / \mathrm{d},\left[\mathrm{C}_{12}(\mathrm{EO})_{23}\right]=322.0 \mathrm{mg} / \mathrm{kg} / \mathrm{d},[\mathrm{GM}]=170 \mathrm{mg} / \mathrm{kg} /$ d, GM-HL 10×: [DMPC] $=6940 \mathrm{mg} / \mathrm{kg} / \mathrm{d},\left[\mathrm{C}_{12}(\mathrm{EO})_{23}\right]=643.9 \mathrm{mg} / \mathrm{kg} / \mathrm{d},[\mathrm{GM}]=340 \mathrm{mg}$ $\mathrm{kg} / \mathrm{d}, \mathrm{GM} 1 \times:[\mathrm{GM}]=34 \mathrm{mg} / \mathrm{kg} / \mathrm{d}, \mathrm{GM} 10 \times:[\mathrm{GM}]=340 \mathrm{mg} / \mathrm{kg} / \mathrm{d}, \mathrm{HL} 1 \times:[\mathrm{DMPC}]=$ $694.0 \mathrm{mg} / \mathrm{kg} / \mathrm{d}, \quad\left[\mathrm{C}_{12}(\mathrm{EO})_{23}\right]=64.39 \mathrm{mg} / \mathrm{kg} / \mathrm{d}, \quad \mathrm{HL} \quad 5 \times: \quad[\mathrm{DMPC}]=3470 \mathrm{mg} / \mathrm{kg} / \mathrm{d}$ $\left[\mathrm{C}_{12}(\mathrm{EO})_{23}\right]=322.0 \mathrm{mg} / \mathrm{kg} / \mathrm{d}$. 
(A) GM-HL 10X

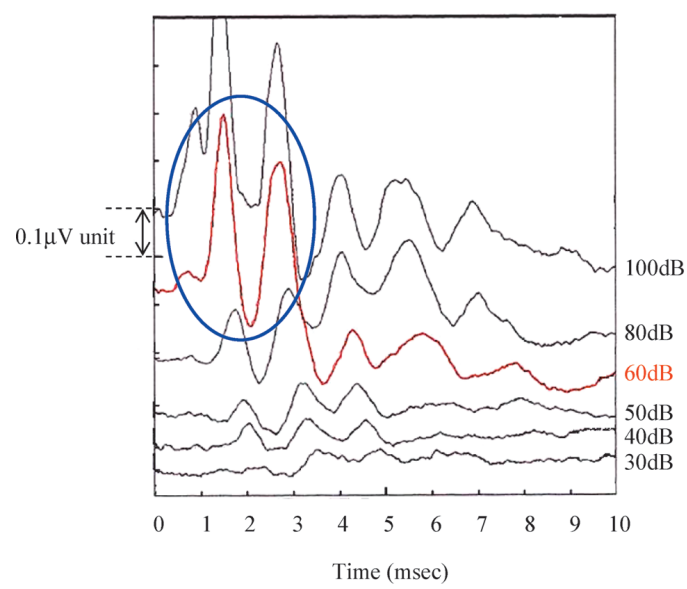

(B) GM 10X

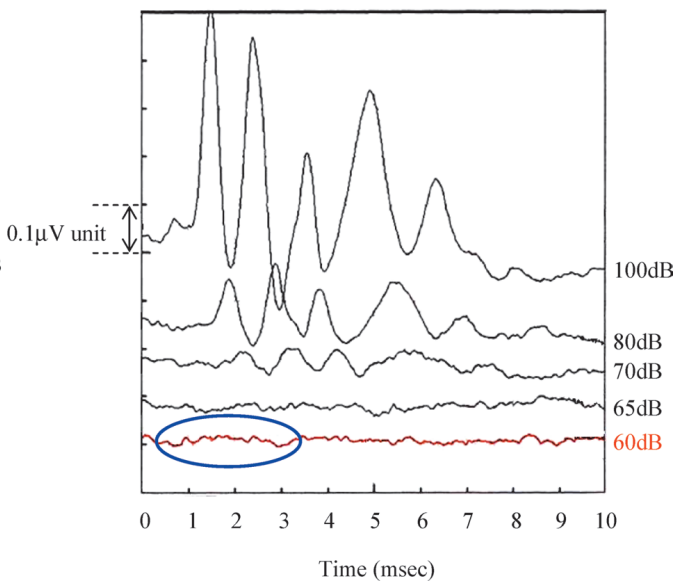

Fig. 5. ABR of Mdx Mice Treated with GM-HL $10 \times$ and GM $10 \times$

After 2 weeks of i.p. injection of (A) GM-HL $10 \times$ and (B) GM 10× in to the mdx mice ( 3 times/d), the ABR was obtained from anesthetized mice in a sound-attenuated box. The responses were differentially recorded between subcutaneous stainless steel electrodes at the vertex (active) and mastoid (reference), and the lower back served as ground using a signal processor. Dose: GM-HL 10×: $[\mathrm{DMPC}]=6940 \mathrm{mg} / \mathrm{kg} / \mathrm{d},\left[\mathrm{C}_{12}(\mathrm{EO})_{23}\right]=643.9 \mathrm{mg} / \mathrm{kg} / \mathrm{d},[\mathrm{GM}]=340 \mathrm{mg} / \mathrm{kg} / \mathrm{d}, \mathrm{GM} 10 \times:[\mathrm{GM}]=340 \mathrm{mg} / \mathrm{kg} / \mathrm{d}$.

(A) Liver

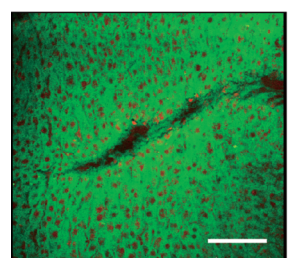

(B) Skeletal muscle

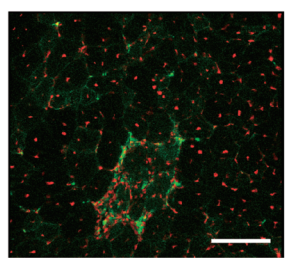

(C) Brain

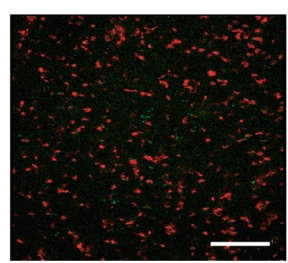

(D) Kidney

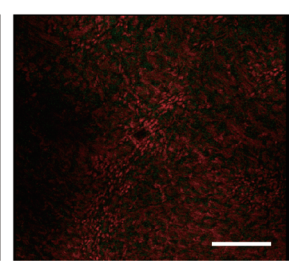

Fig. 6. Biodistribution of NBD-HL in Mdx Mice after i.v. Injection in Vivo

After $1 \mathrm{~h}$ of i.v. injection of NBD-HL into mdx mice, the organs were isolated from the mice. The dissected organs of (A) liver, (B) skeletal muscle, (C) brain and (D) kidney were stained with TO-PRO-3 and the sections were observed using CLM. Green: NBD-HL, Red: TO-PRO-3. Dose: [DMPC] $=67.98 \mathrm{mg} / \mathrm{kg},\left[\mathrm{C}_{12}(\mathrm{EO})_{23}\right]=6.59 \mathrm{mg} / \mathrm{kg}$, $[\mathrm{NBDPC}]=3.76 \mathrm{mg} / \mathrm{kg}$. Scale bar: $100 \mu \mathrm{m}$.

and $10 \times$ were $1521 \pm 422(\mathrm{IU} / 1)$ and $1237 \pm 293(\mathrm{IU} / \mathrm{l})$, respectively. The average CK levels of HL $1 \times$ and $5 \times$ were $2114 \pm 430$ (IU/1) and 2145 \pm 955 (IU/1), respectively. The CK levels of GM-HL injected mdx mice showed a decreasing tendency in comparison with those of HL and GM alone. The total CK levels of GM-HL $(1 \times$ and $5 \times)$, GM $(1 \times$ and $10 \times)$ and HL $1 \times$ significantly decreased in comparison with that of control $(p<0.05)$. Furthermore, the dystrophin immunostaining of skeletal muscle tissues of mdx mice indicated that the dystrophin positive fibers were well observed in GM-HL $10 \times$ injected mice (Fig. 4B) as compared with HL $1 \times$ injected mice (Fig. $4 \mathrm{~A})$. The rate of dystrophin positive fibers of GM-HL $1 \times$, GM-HL $5 \times$, GM-HL $10 \times$, GM $1 \times$, GM $10 \times$, HL $1 \times$, and HL $5 \times$ were $3.87 \pm 0.676 \%$, $5.58 \pm 1.31 \%, \quad 7.73 \pm 4.01 \%, \quad 3.13 \pm 0.718 \%, \quad 4.62 \pm 2.17 \%$, $2.44 \pm 0.835 \%$, and $1.74 \pm 0.450 \%$, respectively as shown in Fig. 4D. The efficiency of dystrophin positive fibers in the GM-HL $10 \times$ injected group was the highest followed by the GM-HL $5 \times$ injected group. The rates of dystrophin positive fibers for GM-HL $(1 \times$ and $5 \times)$ were significantly higher than that for HL $5 \times(p<0.05)$.

Suppression of the Ototoxicity of GM by Using GMHL The ototoxicity of GM-HL on the mdx mice was evaluated by ABR tests in vivo. As shown in Fig. 5, the ABR of the mdx mice after the injection of GM-HL $10 \times$ was observed to $30 \mathrm{~dB}$, though that after the injection of GM $10 \times$ was observed only to $70 \mathrm{~dB}$. The ABR of GM-HL $10 \times$ in- jected mdx mice was normal as observed in the wave of $60 \mathrm{~dB}$, while that of GM $10 \times$ injected mice was abnormal as observed in the wave of $60 \mathrm{~dB}$ and as being almost flat. Furthermore, the biodistribution of NBD-HL in mdx mice after the intravenous (i.v.) injection was examined using CLM. In the organs of brain, liver, kidney, intestine, skeletal muscle and spleen, the accumulation of NBD-HL was observed in the liver (Fig. 6A) and skeletal muscle (Fig. 6B) of mdx mice after $1 \mathrm{~h}$ of the injection. No accumulation of NBD-HL was detected in other organs including the brain (Fig. 6C) and kidney (Fig. 6D).

\section{DISCUSSION}

Pharmacological approaches for DMD with promising candidates for using drugs such as aminoglycoside antibiotics, calcium blokers, steroids, etc. are under investigation. Some of them have been effective for animal models. However, they are not enough to improve the muscle weakness for patients. One of these reasons is that the effective dose as a medicine is not injected to patients because of the severe side effects. For the reduction of the side effects, several DDS utilizing nanopolymers ${ }^{26)}$ and viral vectors ${ }^{27)}$ etc. were reported for the treatment of DMD. However, there were very few reports to achieve the more selective delivery to dystrophic muscles comparing with normal muscles.

In this study, we investigated the effects of DDS using HL 
composed of DMPC and $\mathrm{C}_{12}(\mathrm{EO})_{23}$ as a carrier of GM for DMD therapy in vivo. It is very important to clarify the characteristics such as the size, shape and stability of liposomes in DDS. So, we prepared HL including GM and examined the morphology of GM-HL on the basis of dynamic light scattering measurements and electron microscopy. The hydrodynamic diameters of HL, GM-HL and NBD-HL were 60-90 nm, which remained stable for over 4 weeks (Fig. 1). It is worthy to note that GM-HL having $60-90 \mathrm{~nm}$ in diameter could avoid the reticuloendothelial system in vivo. ${ }^{28)}$ Next, we observed the accumulation of NBD-HL in skeletal muscles of mdx and normal mice in vivo using CLM and demonstrated that HL could accumulate more to myofibers of $\mathrm{mdx}$ mice as compared with those of normal mice (Figs. $2 \mathrm{~A}, \mathrm{~B})$ and retained in the cells at least $6 \mathrm{~h}$ after the injection (Fig. 2E). Significantly, the increasing dystrophin positive fibers in skeletal muscle cells (Fig. 4) and decreasing CK levels (Fig. 3) in the blood of mdx mice were observed after the treatment with GM-HL. It is suggested that GM should be carried more efficiently into the muscular cells of mdx mice by HL. These results indicate that GM-HL could be more effective for DMD therapy than GM alone. Furthermore, we evaluated the ototoxicity of GM-HL on the $\mathrm{mdx}$ mice by ABR tests and the results indicated that GM-HL $10 \times$ suppressed the ototoxicity in mdx mice (Fig. 5). In addition, the serum creatinine concentrations of GM-HL injected $\mathrm{mdx}$ mice were normal (data not shown), suggesting that GM-HL could suppress nephrotoxicity. Three of 4 GM 10× injected mice lost $1-2 \mathrm{~g}$ of weight, while the GM-HL $10 \times$ injected mice gained weight (data not shown). It is attractive that HLGM have not only more therapeutic effects but also less side effects as compared with GM alone. Finally, we examined the biodistribution of $\mathrm{HL}$ in $\mathrm{mdx}$ mice via i.v. injections in vivo in order to investigate the possibility of clinical applications in the future. The accumulation of NBD-HL was observed in the liver and skeletal muscle in comparison with other organs after $1 \mathrm{~h}$ of the i.v. injection (Figs. 6A, B). Especially, the accumulation was hardly observed in brain (Fig. 6C) and kidney (Fig. 6D). In the previous paper, we indicated the same biodistribution of NBD-HL except skeletal muscle in the normal mice. ${ }^{29)}$ These results suggest that HL could be metabolized in liver, and the toxicities of GM to kidney and auditory nerve systems could be suppressed by using HL as the drug carrier.

The first advantage of using HL as DDS is that this system could reduce toxicity. The second one is that the dosage could be stable for more than 4 weeks. The third one is that it could allow an escape from the reticuloendothelial system. The results obtained in this study suggest that the DDS with HL could be applied in the novel therapy using GM for patients with DMD.

Acknowledgements The authors thank Ryan Pruchnic (Cook MyoSite, Pittsburgh, Penn) for his assistance. This work was supported in part by Grant-in-Aids for Science Research from the Ministry of Education, Culture, Sports, Science and Technology of Japan (Nos. 20107007, 20360377, 20560732, 19560782, 21560813, 19591209) and a Research Grant (19-7) for nervous and mental disorders from the Ministry of Health, Labour, and Welfare.

\section{REFERENCES}

1) Hoffman E. P., Brown R. H. Jr., Kunkel L. M., Cell, 51, 919-928 (1987).

2) Koenig M., Hoffman E. P., Bertelson C. J., Monaco A. P., Feener C., Kunkel L. M., Cell, 50, 509—517 (1987).

3) Gillard E. F., Chamberlain J. S., Murphy E. G., Duff C. L., Smith B., Burghes A. H. M., Thompson M. W., Sutherland J., Oss I., Bodrug S. E., Klamut H. J., Ray P. N., Worton R. G., Am. J. Hum. Genet., 45, 507-520 (1989).

4) Forrest S. M., Cross G. S., Flint T., Speer A., Robson K. J., Davies K. E., Genomics, 2, 109-114 (1988).

5) Lindlöf M., Kiuru A., Kääriäinen H., Kalimo H., Lang H., Pihko H., Rapola J., Somer H., Somer M., Savontaus M. L., de la Chapelle A., Am. J. Hum. Genet., 44, 496-503 (1989).

6) Prior T. W., Wenger G. D., Papp A. C., Snyder P. J., Sedra M. S., Bartolo C., Moore J. W., Highsmith W. E., Hum. Mutat., 5, 263-268 (1995).

7) Mendell J. R., Buzin C. H., Feng J., Yan J., Serrano C., Sangani D. S., Wall C., Prior T. W., Sommer S. S., Neurology, 57, 645-650 (2001).

8) Howard M., Frizzell R. A., Bedwell D. M., Nat. Med., 2, 467-469 (1996).

9) Howard M. T., Shirts B. H., Petros L. M., Flanigan K. M., Gesteland R. F., Atkins J. F., Ann. Neurol., 48, 164-169 (2000).

10) Barton-Davis E. R., Cordier L., Shoturma D. I., Leland S. E., Sweeney H. L., J. Clin. Invest., 104, 375-381 (1999).

11) Welch E. M., Barton E. R., Zhuo J., Tomizawa Y., Friesen W. J., Trifillis P., Paushkin S., Patel M., Trotta C. R., Hwang S., Wilde R. G., Karp G., Takasugi J., Chen G., Jones S., Ren H., Moon Y. C., Corson D., Turpoff A. A., Campbell J. A., Conn M. M., Khan A., Almstead N. G., Hedrick J., Mollin A., Risher N., Weetall M., Yeh S., Branstrom A. A., Colacino J. M., Babiak J., Ju W. D., Hirawat S., Northcutt V. J., Miller L. L., Spatrick P., He F., Kawana M., Feng H., Jacobson A., Peltz S. W., Sweeney H. L., Nature (London), 447, 87-91 (2007).

12) PTC THERAPEUTICS. "Ataluen for Genetic Disorders." $\langle$ http://www.ptcbio.com/3.1.1_genetic_disorders.aspx $\rangle$.

13) Ueoka R., Moss R. A., Swarup S., Matsumoto Y., Strauss G., Murakami Y., J. Am. Chem. Soc., 107, 2185-2186 (1985).

14) Ueoka R., Matsumoto Y., Moss R. A., Swarup S., Sugii A., Harada K., Kikuchi J., Murakami Y., J. Am. Chem. Soc., 110, 1588-1595 (1988).

15) Kitamura I., Kochi M., Matsumoto Y., Ueoka R., Kuratsu J., Ushio Y., Cancer Res., 56, 3986-3992 (1996).

16) Matsumoto Y., Kato T., Suzuki H., Hirose S., Naiki Y., Hirashima M., Ueoka R., Bioorg. Med. Chem. Lett., 10, 2617-2619 (2000).

17) Tanaka Y., Goto K., Matsumoto Y., Ueoka R., Int. J. Pharm., 359, 264-271 (2008).

18) Matsumoto Y., Kato T., Iseki S., Suzuki H., Nakano K., Iwahara M., Ueoka R., Bioorg. Med. Chem. Lett., 9, 1937-1940 (1999).

19) Ueoka R., Matsumoto Y., Ichihara H., Kiyokawa T., "Chemotherapy with Hybrid Liposomes Composed of Dimyristoylphosphatidylcholine and Polyoxyethylenealkyl Ether without Drugs," ACS Symposium Series 830, Biological Systems Engineering, Chap. 14, ed. by Marten M. R., Park T. H., Nagamune T., Am. Chem. Soc. Books, Washington, 2002, pp. 177-189.

20) Matsumoto Y., Iwamoto Y., Matsushita T., Ueoka R., Int. J. Cancer, 115, 377-382 (2005).

21) Ichihara H., Nagami H., Kiyokawa T., Matsumoto Y., Ueoka R., Anticancer Res., 28, 1187-1196 (2008).

22) Komizu Y., Matsumoto Y., Ueoka R., Bioorg. Med. Chem. Lett., 16, 6131-6134 (2006)

23) Nakashima K., Miyagi M., Goto K., Matsumoto Y., Ueoka R., Yakugaku Zasshi, 124, 231-235 (2004).

24) Nakano K., Iwamoto Y., Takata W., Matsumoto Y., Ueoka R., Bioorg. Med. Chem. Lett., 12, 3251-3254 (2002).

25) Hakuba N., Koga K., Gyo K., Usami S., Tanaka K., J. Neurosci., 20, $8750-8753$ (2000)

26) Williams J. H., Schray R. C., Sirsi S. R., Lutz G. J., BMC Biotechnol., 8, 35- 47 (2008).

27) Gregorevic P., Blankiship M. J., Allen J. M., Crawford R. W., Meuse L., Miller D. G., Russell D. W., Chamberlain J. S., Nat. Med., 10, 828 -834 (2004).

28) Allen T. M., Hansen C., Martin F., Redemann C., Yau-Young A., Biochem. Biophys. Acta, 1066, 29-36 (1991).

29) Ichihara H., Nagami H., Yamamoto K., Matsumoto Y., Ueoka R., Yakugaku Zasshi, 123, 25-34 (2003). 